\title{
A novel hydraulic fracturing gel realization for unconventional reservoirs
}

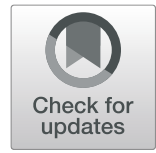

R. V. V. Ramana Murthy ${ }^{1}$ and Murthy Chavali $1^{1,23^{*}}$

\begin{abstract}
Coal bed methane reservoirs possess low to ultra-low permeability. In order to improve the production from CBM wells, stimulation techniques were deployed.

Background: This article reviews the most cost-effective, time-saving, and eco-friendly fracturing fluid which is a mix of water, guar gum, and sodium acetate. This article also provides a detailed study of hydraulic fracturing in unconventional reservoirs.

Results: Unlike using diesel, biodiesel we have prepared a cost-effective frac-fluid which is not having any smoke point which depicts it as eco-friendly fluid. In this method there is no requirement of anti-settling agents, suspending agents, emulsifiers. Gel breakers are more efficient to break the linear gel.

Conclusion: The breakers inorganic compound ammonium persulfate and hemicellulose liquid. A reaction takes place on linear gel as it breaks slowly at down hole static temperature at $50^{\circ} \mathrm{C}$ and $65^{\circ} \mathrm{C}$. So, experimental studies also prove this method is applicable for unconventional reservoir operations.
\end{abstract}

Keywords: Unconventional well, Fracturing gel, Fragmentation, Oxidizers, Enzyme

\section{Background}

The unconventional reservoirs are which are not easy to be produced due to both very low porosity and permeability; hydraulic fracturing linear gel were prepared with basic hydrocarbons reported earlier by our group. Hydraulic fracturing is pumping of gel at high pressure under bottom hole static temperature [1]. According to the literature of past research work case study, conventional and unconventional wells depends on the area, and then the technique were water fracturing, lowtemperature fluid, and cross-linker fluid [2]. The background of any frac fluids is guar gum (Fig. 1). Guar gum was an affinity to water then it foams a long polymer gel and high molecular weight (Fig. 2). Guar gum, also known as guaran, is a galactomannan polysaccharide

\footnotetext{
*Correspondence: ChavaliM@gmail.com; ChavaliM@outlook.com

'Division of Chemistry, Department of Sciences and Humanities, Vignan's

Foundation for Science, Technology and Research University (VFSTR

University; Vignan's University), Vadlamudi, Guntur, Andhra Pradesh 522 213,

India

${ }^{2}$ Shree Velagapudi Ramakrishna Memorial College, Nagaram, Guntur Dt, AP

522 268, India

Full list of author information is available at the end of the article
}

obtained from guar beans that has thickening and stabilizing properties useful in the food, feed, and industrial applications [3]. The guar seeds are mechanically dehusked, hydrated, milled, and screened according to its application. Characteristically, it is produced as a freeflowing, off-white powder.

The guar gum has many derivatives like gymer composed, Mannose, and galactose. Now a day, more derivatives are looking very fine gives good viscosity properties. Guar gum powder is hydrated with water then the molecules unfold tends to which elevator the viscosity of the solution [4]. The solution has been established as water blocking agents in hydraulic fracturing. The frac additives added to the linear gel increased friction reducers, corrosion inhibitors and also organic compounds which kills bacterial in damaged wells [5]. Hydraulic fracturing is an innovative technique used to produce coal bed methane gas from extremely low permeability rock. The old technique was utilizing in high-temperature areas with slickwater which is mixing with frac additives, it is low cost and has less environmental effect [6]. Frequently, the gelling agents in fracturing fluids are guar gum derivatives 

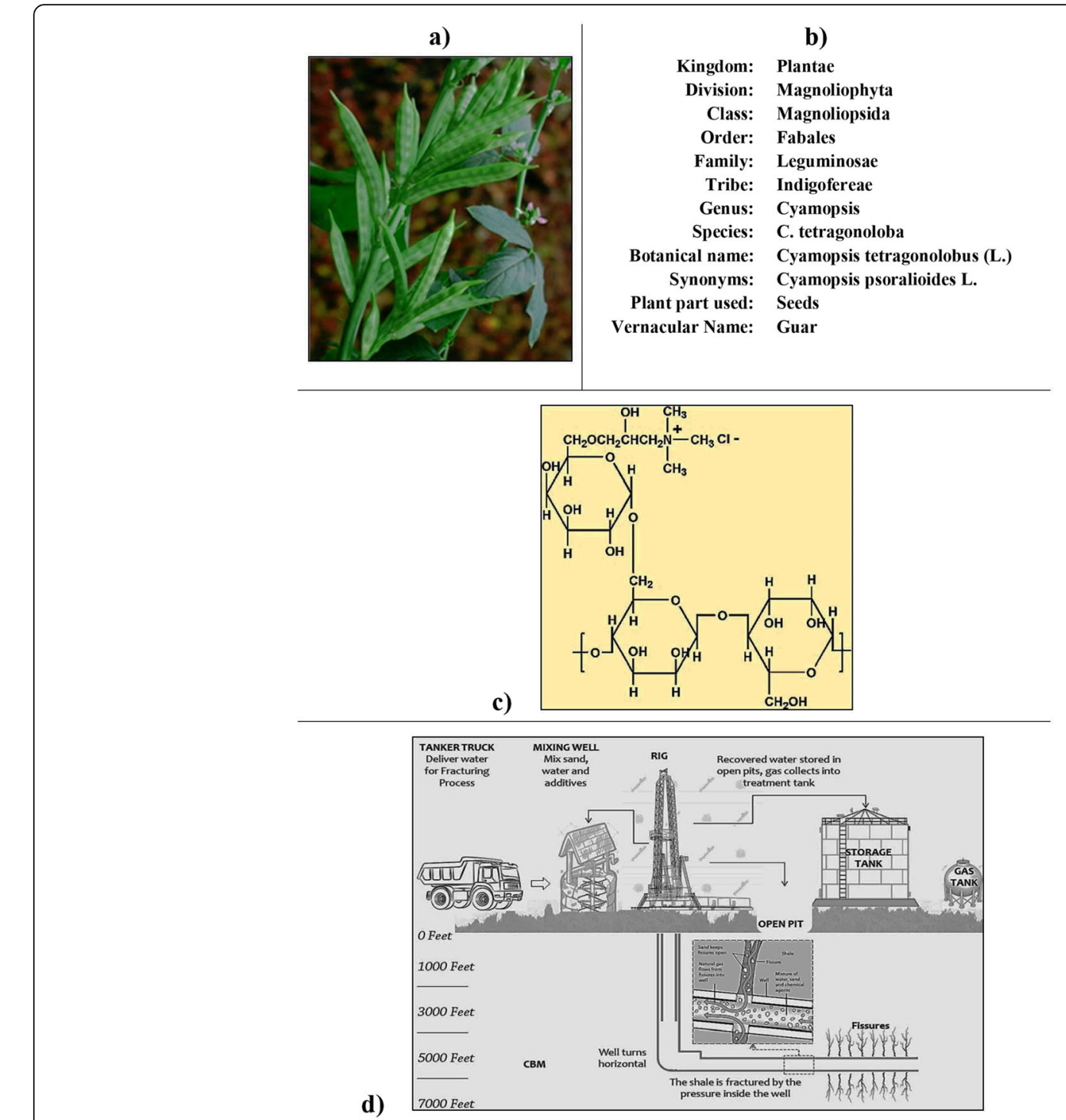

\section{b)}

Fig. 1 a Guar gum plant. b Guar scientific classification. c Chemical structure of guar gum. d Hydraulic fracturing process

such as hydroxyl propyl guar and carboxymethyl hydroxyl propyl guar [7]. The Linear gel should maintain basic nature while preparation of gel [8]. It is a friction reducer, anionic due to its lower cost and better drag reduction [9]. Typically, the anaerobic sulfate-reducing bacteria found in conventional formation and it affects production casing, in that aspects biocide should be added in linear gel to avoid from anaerobic bacteria in the reservoir [10].

Not only in petroleum fluid also Guar gum used for a good gumming agent in food and bakery purpose [11]. The guar polymer solution is mixed with some friction reducers easy to move and carrying 20/40 mesh size proppant into the fractured area [12]. The formulations and open up new opportunities for guar usage [13]. In CBM wells, the proppant conductivity drops considerably in the presence of water due to the rock-fluid interactions soften the rock leading to proppant embedment [14]. Almost all dry powders increase the viscosity of the gel after adding drill water sample [15]. Linear gels control fluid loss very well, whereas in higher permeability formations fluid loss can be excessive [16]. Linear gels tend to form thick filter cakes on the face of lower-permeability formations [17]. In this research work, we observed that multiple fractures were also done, during both the main frac job in the field [18]. Based on all literature surveys, the guar gum is multidimensions purpose for oil recovery in fracturing and stimulation. Slick water is the mixer of water, $2 \%$ of $\mathrm{KCL}$ and $2 \mathrm{gal} / 1000 \mathrm{gal}$ friction reducers are polyacrylic acid, polyacrylamide, hydrolyzed polyacrylamide, and acrylamido methylpropane sulfonate [19]. Slick water is to reduce friction in production tubing and casing, it has low 

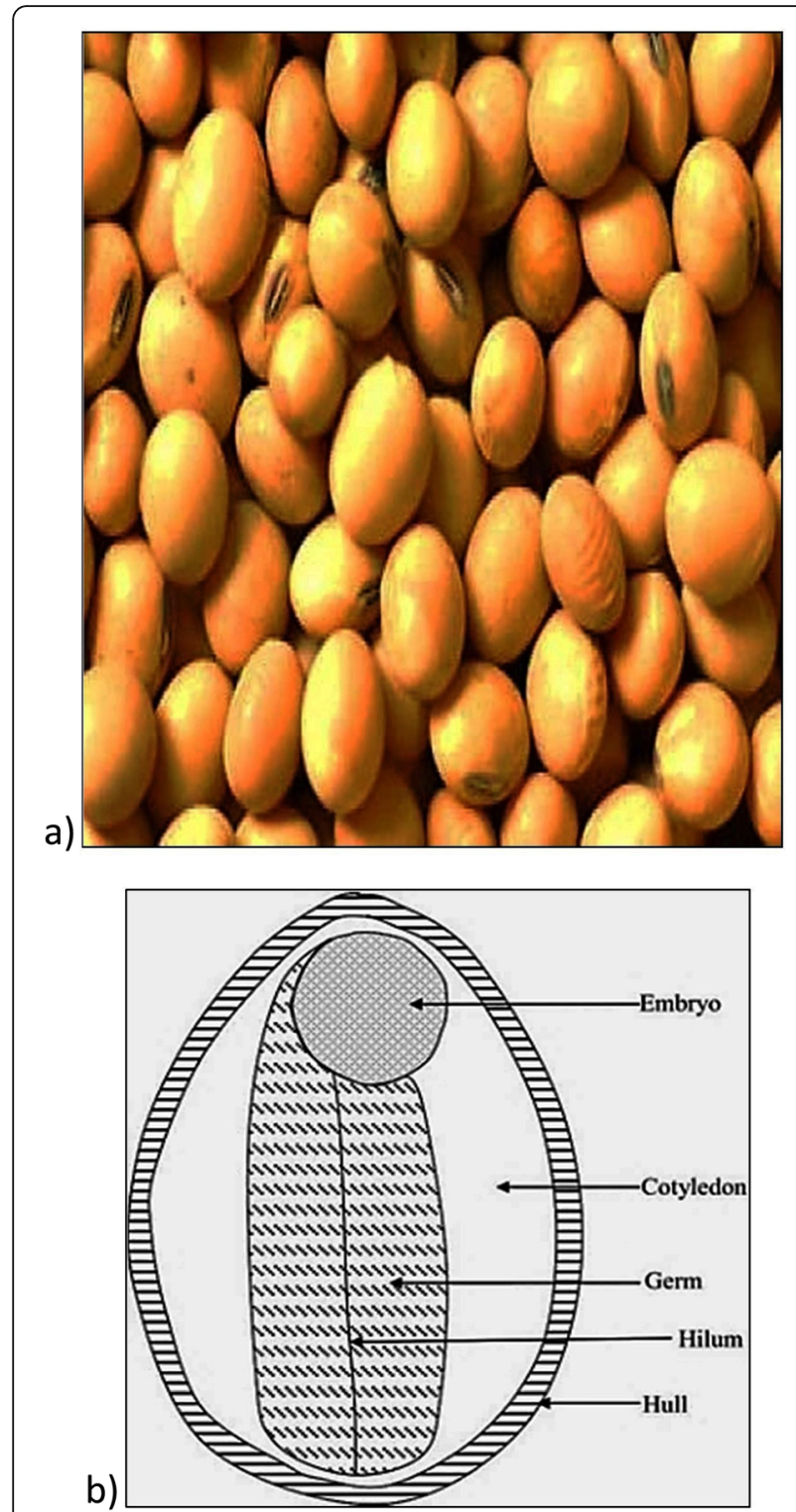

Fig. 2 a Guar seeds. b Seed anatomy

viscosity and high pumping rate carry with low proppant concentrations [20]. The friction reducer is often used to reduce the flowing friction in the wellbore during hydro frac, breaker is also pumped into the wellbore to degrade the friction reducers in gas-tight wells cases [21]. The majority of unconventional gas reservoirs are tight gas, shale gas, coal bed methane gas, tight gas is the natural gas store in conventional limestone and sandstone reservoir and its dimension is less than $0.1 \mathrm{mD}$ matrix permeability and less than $10 \%$ matrix porosity [22]. The shale gas is also natural gas that is found trapped within shale formation area [23]. Coal bed methane gas is the natural gas extracted from coal beds formations, it is also called "sweet gas" because of it lack hydrogen sulfide and distinct from the typical sandstone and other conventional reservoirs [24]. The aim of this research work is a new technique with novel designed of the linear gel realization for unconventional wells to enhancing challenging production rate, reduce the damaged wells, feasible production flow, and typically less expansive with eco-friendly. The formulation of fracturing fluid is the combination of drill water + anti-settling agents + 20/40 mesh size of sand.

\section{Methods}

\subsection{Experimental studies}

Drill water, sodium bicarbonate as a buffering agent, guar gum powder (Fig. 3). Two breakers, ammonium persulfate which is in solid-state and another one is liquid hemicellulase enzyme-G. Gas flow which is in a liquid state (the composition of methanol 2-butoxyethanol ethylene oxide nonyl-phenol polymer alcohols, C12-16, ethoxylated tridecyl alcohol nonylphenol ethoxylated nonionic surfactant).It will flow back after fracturing. 20/40 mesh size sand. $\mathrm{X}$-cide is a composition formed from ingredients comprising peroxide and hypochlorite.

\subsection{Drill water testing}

For every frac job before water analysis should be check, the parameters of water will affect more during the formation of gel hydration. If water has more $\mathrm{pH}$, hardness, chlorides, and iron leads to gel break very quickly. The following parameters should be checked before testing as shown in Table 1. X-cide should be added before acid job and frac job.

\subsection{Rheometer to check the viscosity}

A direct viscosity reading in centipoises (cp) was obtained by taking the $300 \mathrm{rpm}$ reading of VG meter with

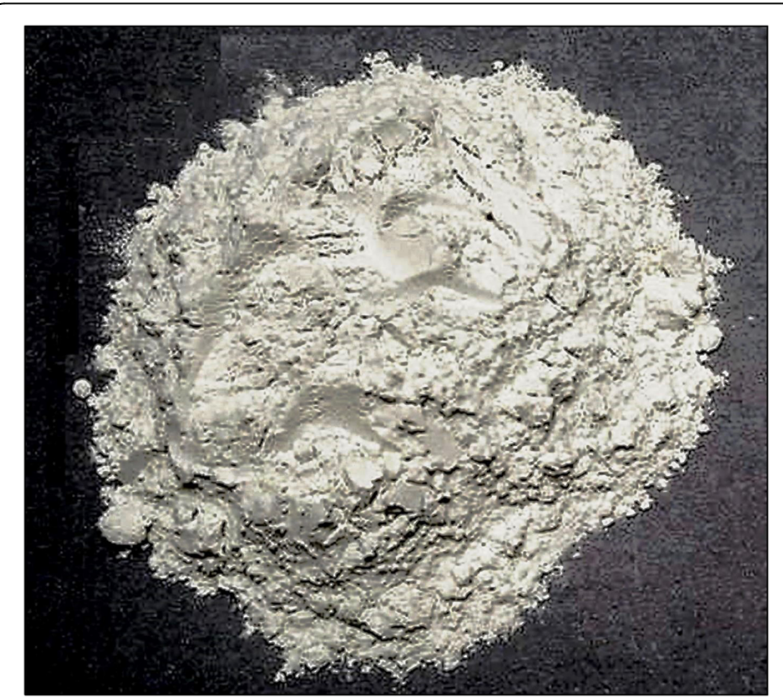

Fig. 3 Guar gum powder 
Table 1 Test1 (sample water)

\begin{tabular}{ll}
\hline Parameters & Measured values \\
\hline Clarity & Clear \\
Sample temperature, ${ }^{\circ} \mathrm{C}$ & 24 \\
Specific gravity & 1 \\
Initial pH & 7.1 \\
Iron $\left(\mathrm{Fe}^{2+} / \mathrm{Fe}^{3+}\right), \mathrm{ppm}$ & 1 \\
Chloride, ppm & 350 \\
Total hardness, ppm & 70 \\
Bicarbonate, ppm & 710 \\
Sulfates, ppm & 220 \\
TDS, ppm & 20,500 \\
Reducing agent & Negative \\
Bacteria & 500,500 \\
\hline
\end{tabular}

Rheometer (FI spring, BI bob, and Rotor). The viscosity of gel was measured when the gel exhibit stringy and pourable behavior. So, the apparent viscosity of gel was determined using the Fann 35 Rheometer. Viscosity is shear stress divided by shear rate, so viscosity in centipoise $=$ dail reading $\times$ factor. As per traditional speeds for API viscosity for $300 \mathrm{rpm}$ factor is 1 .

\subsection{Linear gel hydration method}

Take mixer which has a capacity of $2500 \mathrm{rpm}$, as per 7.5 gpt design calculation $309 \mathrm{ml}$ of water taken into 1000 $\mathrm{ml}$ capacity blender. Sixty grams of sodium bicarbonate powder was needed to add to the blender. It is a buffering agent for neutralizing the solution. Then, check the $\mathrm{pH}$ of the solution thoroughly. Make sure sodium bicarbonate should be dispersed and lump-free. At $2500 \mathrm{rpm}$ up to $25 \mathrm{~min}$, the solution should be maintained in basic nature [Fig. 4]. Add $240 \mathrm{~g}$ of guar gum and continue the mixing for 30 min until the gel gets smooth and lumpfree. Then, measure the density of the gel by using mud balance. Check the viscosity of the linear gel; finally, we got $32 \mathrm{cp}$ viscosity.

\section{Results}

\subsection{Breaker test}

Breakers are added to the frac liquid to lessen the atomic load of the different polymers utilized. This decreases the thickness and encourages the blowback of remaining polymer which takes into account cleanup of the proppant pack. Ammonium persulfate breaker is a very strong oxidizer which forms free oxygen radical at temperature $50{ }^{\circ} \mathrm{C}$ above, it works on cleaving the acetyl linkage in the polymer backbone as shown in Fig. 5. The free radicals attack the backbone of the polymer and break into its constitutive sugars. The breaking action is controlled by the solution by the rate of the peroxide into the water. Ammonium persulfate has strong

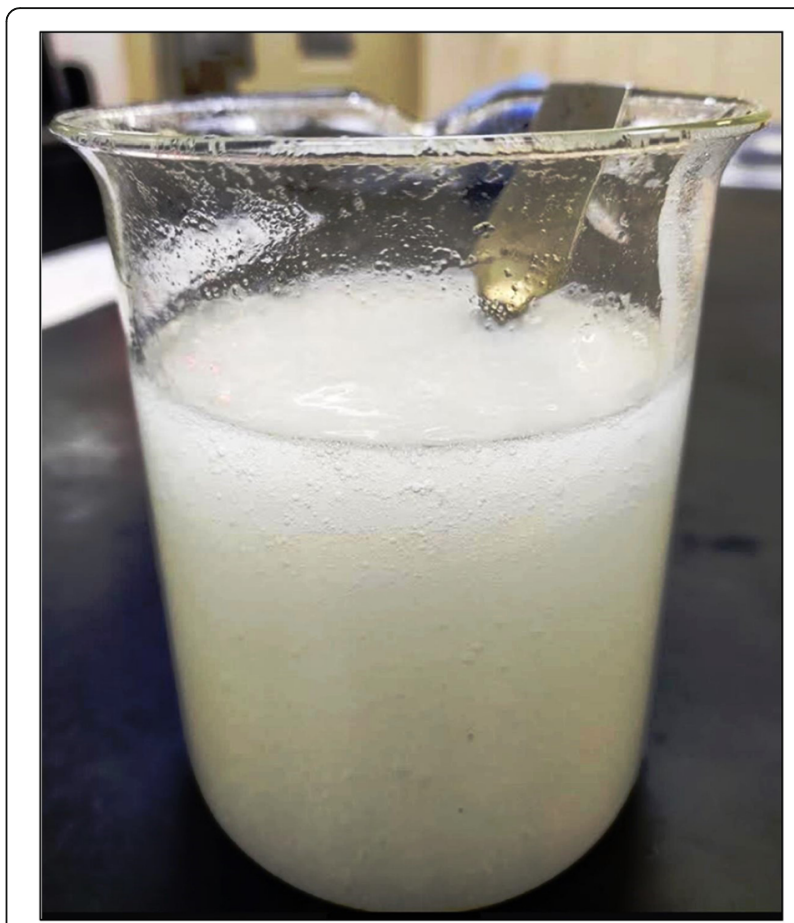

Fig. 4 Instant linear gel formation

oxidizing agents and will produce a very active fire when exposed to organic material; it was used in frac operation for applications such as a water disinfectant, bleach, and pickling agents for metals. Hemicellulase enzyme- $G$ is a protein molecule, and it acts as organic catalyst that attacks and digests the polymer at specific sites along the polymer backbone. The release rate of the breaker in this type is controlled by hydrostatic pressure, elevated temperatures and the $\mathrm{pH}$ of the fracturing fluid was maintained in basic nature until breaking the gel. In our pilot test, we tested with 1 ppt ammonium persulfate and 1 gpt enzyme-g concentration at $50{ }^{\circ} \mathrm{C}$ and $65{ }^{\circ} \mathrm{C}$ temperatures. These two temperatures are well known conditions taken from CBM formations at Durgapur, West Bengal.

\subsection{Unit conversions}

$$
\begin{aligned}
1 \text { ppt } & =\frac{1 \text { pound }}{(1000 \times 1 \text { gallon })}=\frac{1 \times 453.2}{(1000 \times 1 \times 3.782)} \\
& =\frac{453.2}{3782}=0.12 \text { gms } / \text { lit }
\end{aligned}
$$

Where $453.2 \mathrm{~g}$ is a factor, 1 gallon $=3.782 \mathrm{l}$

$$
1 \text { gpt }=\frac{1 \text { gallon }}{1000 \text { gallons }}=\frac{1 \mathrm{ltr}}{1000 \mathrm{ltr}}=\frac{1 \mathrm{ml}}{1000 \mathrm{ml}}
$$




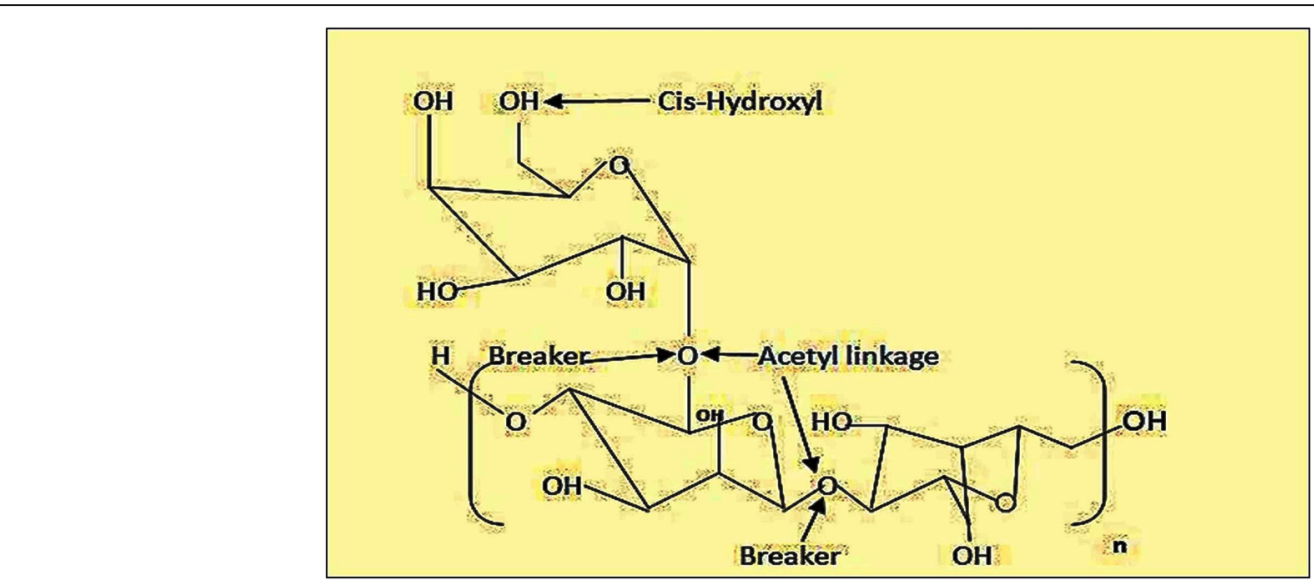

Fig. 5 Process of the breaking of linear gel

Then, add a small amount of ammonium persulfate and enzyme-G into a linear gel glass bottle and shake it well. Put it in water baths which are maintained at $65{ }^{\circ} \mathrm{C}$ and $50{ }^{\circ} \mathrm{C}$ temperature, now check the viscosity for every $10 \mathrm{~min}$.

\subsection{Polymer reaction}

\begin{tabular}{|l||}
\hline \multicolumn{1}{|c||}{ Fragmentation } \\
$\mathrm{X}-\mathrm{Y} \rightarrow \mathrm{X}+\mathrm{Y}$ \\
$\mathrm{X}-\mathrm{Y}$ fragments to $\mathrm{X}$ and $\mathrm{Y}$ \\
\hline
\end{tabular}

The gel viscosity is $32 \mathrm{cp}$, then it was tested at well conditions, and the static temperature is $50{ }^{\circ} \mathrm{C}$ and $65{ }^{\circ} \mathrm{C}$, breaker dosage of $1 \mathrm{ppt}$ ammonium persulfate and 1gpt enzyme-G breakers added into the linear gel, then the linear gel viscosity will break gradually.

Table 2 shows that for every $10 \mathrm{~min}$, gel breaks gradually up to $120 \mathrm{~min}$. Usually, the gel carries $20-40$ sand dimension, oxidizers and gas flow solution injected into well under high-pressure form fissures. After linear gel is pumped into perforated holes then the fragmentation reaction takes place. The viscosity of linear gel becomes watery gradually. After $2 \mathrm{~h}$, the gel totally will break and converts into the water, the gas flow will return back as flow-back water. This flow back water again can then be used for production of water after the reverse osmosis process.

The ratio of mannose and galactose is similar (1.8:1), and it belongs to polysaccharide group mannose backbone and weight of galactose side unit as shown in Fig. 5. The polymer stored in endosperm of the guar beans. The total molecular weight is similar to $2,000,000$. Ploy mannose is insoluble in water; insoluble residue is nearly 6 to $10 \%$.

\section{Discussion}

In this article, the most interesting part is eco-friendly. Our aim is to avoid pollution in villages and cities in drilling areas. Simply, we used water for preparation of linear gel for low temperatures wells for unconventional reservoirs. Instead of hydrocarbons, fossil diesel replaced water obtained a great result in hydraulic fracturing. This technique is made the linear gel in off-shore rig and on-shore rig operations very easy to prepare. The pilot test is done at Durgapur, West Bengal. Coal bed methane gas wells operations successes result obtained by using linear gel. In this research work, we did not use hazardous chemicals and costly chemicals. Economically very cheap additives and low cost for digging the hydraulic fracturing services for off-shore and on-shore operations. A very small quantity of oxidizing agents were used to break the linear gel; it conveys proppant into cracks, breaks gel at static temperature, and it changes over into water after oxidation response, with the assistance of gas stream substance water stream from arrangement to

Table 2 Test-2 breaker test result (7.5 gpt gel under breaker concentration at 1 ppt oxidizer and 1 gpt enzyme-G)

\begin{tabular}{llll}
\hline S. No & Gel breaking time (min) & \multicolumn{2}{l}{$\begin{array}{l}\text { Linear gel viscosity } \\
1 \text { ppt and } 1 \text { gpt breaker }\end{array}$} \\
\cline { 3 - 4 } & & $65^{\circ} \mathrm{C}$ & $50^{\circ} \mathrm{C}$ \\
\hline 1 & 0 & 32 & 32 \\
2 & 10 & 26 & 25 \\
3 & 20 & 23 & 24 \\
4 & 30 & 21 & 23 \\
5 & 40 & 19 & 20 \\
6 & 50 & 16 & 15 \\
7 & 60 & 13 & 12 \\
8 & 90 & 10 & 13 \\
9 & 120 & 5 & 7 \\
\hline
\end{tabular}


surface. An application of this fluid shows an impact on hydraulic fracturing substantially increases the extraction of natural gas from unconventional sources.

\section{Conclusion}

The budget of linear gel is very less and more efficient results than the slick water. Now the oil field companies can use this fluid design for unconventional reservoirs. The linear gel can prepare instantly within $1 \mathrm{~h}$ and can be stored in a hydration unit for $36 \mathrm{~h}$. As per client requirement, the operators will pump linear gel into well after perforation. This work can be applied for CBM for extreme operations. There is potential to reduce gel damage areas at expired wells. This is typically less expensive and successful results in more complex fracturing. It concerns good ability proppant transport both frac length and vertical coverage. In the future, we can recommend extending of this work to high-temperature and high-pressure wells by applying to borate cross-link additive towards cross-link gel fluids. A comprehensive experimental method has developed to study on over the old technique-oriented fluids, now applied novel gel with new technique in all CBM wells tested up to maximum well temperatures.

\section{Abbreviations}

CBM: Coal bed methane gas; CP: Centipoises; GPT: Gallon per thousand gallon; PPM: Parts per million; PPT: Pounds per thousand gallon; RPM: Revolutions per minute

\section{Acknowledgements}

The authors(s) wish to express their appreciation to frac department. We also express our Thanks to lab team members for providing assistance throughout this research work.

\section{Authors' contributions}

$M C$ has contributed the major work in writing the manuscript, alignment and the experimental part of the manuscript. Both the authors read and approved the final manuscript.

\section{Funding}

No funding sources, individual research

\section{Availability of data and materials}

Not applicable.

\section{Ethics approval and consent to participate}

Not applicable.

\section{Consent for publication}

Not applicable.

\section{Competing interests}

The authors declare that they have no competing interests.

\section{Author details}

'Division of Chemistry, Department of Sciences and Humanities, Vignan's Foundation for Science, Technology and Research University (VFSTR University; Vignan's University), Vadlamudi, Guntur, Andhra Pradesh 522 213, India. ${ }^{2}$ Shree Velagapudi Ramakrishna Memorial College, Nagaram, Guntur Dt, AP 522 268, India. ${ }^{3}$ NTRC, MCETRC, Tenali, Guntur, Andhra Pradesh 522 201, India.
Received: 3 October 2019 Accepted: 4 June 2020

Published online: 15 September 2020

\section{References}

1. Wang T, Li H, Wang J, Jia Y, Liu L (2015) Volumetric source model to predict the productivity of fractured horizontal well in naturally fractured reservoirs. Open Petroleum Eng J 8:373-384

2. Romero Zeron LB, Hum FM, Kantzas A (2008) Characterization of crosslinked gel kinetics and gel strength by use of NMR. DOl: https://doi.org/10. 2118/86548-PA

3. Wang Q, Peter RE, Ross-Murphy SB (2006) The dissolution kinetics of guar gum powders - III. Effect of particle size. Carbohyd Polym 64:239-246

4. Sorbie KS (1991) Polymer Improved Oil Recovery. Springer Science, Newyork

5. Yew CH, Weng X (2015) Mechanics of hydraulic fracturing, 2nd edn. Elsevier Inc., USA

6. Gu H, Siebrits E, Sabourov A. (2008) Hydraulic fracture modelling with bedding plane interfacial slip. In: SPE Eastern Regional/AAPG Eastern Section Joint Meeting, Pittsburgh, Pennsylvania, USA, 11-15 October 2008.

7. Zhang F, Ma G, Liu X, Tao Y, Feng D, et al. (2018) Experimental analysis of multiple factors on hydraulic fracturing in coalbed methane reservoirs. PLOS One 13(4): e0195363. https://doi.org/10.1371/journal.pone.0195363.

8. Zhixi Chen, Naseeruddin Khaja, Karen Valencia, Sheikh S Rahman (2006) Formation damage induced by fracture fluids in coalbed methane reservoirs. In: SPE Asia Pacific Oil \& Gas Conference and Exhibition, Society of petroleum engineers, Australia, 11-13 September 2006.

9. Chen SB, Zhu YM, Liu TY (2009) Impact of the clear fracturing fluid on the adsorption properties of CBM. J China Coal Soc. 31(1): 89-94. https://doi. org/10.2118/176297-PA.

10. Wang C, Ma D, He Q, Le Q, Liu P (2017) Optimization design of fracturing parameters for coal bed methane wells in Dafosi Mine Field. Sci Res. 9:121131. https://doi.org/10.4236/jpee.2017.59010

11. Kang Yili, Chen Defei, Li Xiangchen (2014) Influence of fracturing fluid treatment on the pore structure of coal and rock. Journal of China University of Petroleum (Natural Science Edition), (5):102-108. DOI: https://doi.org/10.3969/j.issn.1673-5005.2014.05.014

12. Olsen TN, Brenize G, Frenzel T (2003) Improvement processes for coalbed natural gas completion and stimulation. In: SPE Annual Technical Conference and Exhibition, Denver, Colorado, 5-8.

13. Barree RD (1998) Applications of pre-frac injection/falloff tests in fissured reservoirs - field examples. in: spe rocky mountain regional/low permeability reservoirs symposium and exhibition, Denver, Colorado, 5-8 April 1998.

14. Tarokh A, Blanksma DJ, Fakhimi A, AJF L (2016) Fracture initiation in cavity expansion of rock. Int J Rock Mech Min Sci. 85:84-91

15. Xu L, Zhu K, Yang X (2016) Production forecasting of coalbed methane wells based on type-2 Fuzzy logic system. Open Petroleum Eng J 9:268-278. https://doi.org/10.2174/1874834101609010268

16. Li T, Wan J-F (2017) Study of Cyclic Fracturing in Vertical CBM Wells. Open Petroleum Eng J 10:108-117. https://doi.org/10.2174/ 1874834101710010108

17. Roman AG, Ahmadi KA, Issen SDH (2012) Permeability of fractured media under confining pressure: A simplified model. Open Petroleum Eng J 5:3641. https://doi.org/10.2174/1874834101205010036

18. Huang Q, Liu S, Wang G, Wu B, Zhang Y (2019) Coalbed methane reservoir stimulation using guar-based fracturing fluid. J Nat Gas Sci Eng. 66:107-125

19. Carl Montgomery (2013) Fracturing Fluid Components. Intech open access, https://doi.org/10.5772/56422.

20. Carman, P. S, \& Cawiezel, K. E. Successful breaker optimization for polyacrylamidefriction reducers used in slickwater fracturing SPE 106162 presented at the (2007) Hydraulic Fracturing Conference, College Station, Texas, January., 29-31.

21. Woodworth, T. R. and Miskimins, J. L. Extrapolation of laboratory proppant placement behavior to the field in slickwater fracturing applications. Presented at the, 2007/1/1/. https://doi.org/10.2118/106089-MS.

22. Yu, M. and Lau, H.-C. 2013. Production Technology Challenges of Tight and Shale Gas Production in China. Presented at the International Petroleum Technology Conference, Beijing, China 26-28 March 2013. https://doi.org/10. 2523/17096-MS

23. Zhang, S., Klimentidis, R. E. and Barthelemy, P. 2011. Porosity and permeability analysis on nanoscale FIB-SEM 3d Imaging of Shale Rock. 
Presented at the International Symposium of the Society of Core Analysts, Austin, Texas, USA, 18-21 September 2011.

24. Tiab, D. and Donaldson, E. C. (2011). Petrophysics: theory and practice of measuring reservoir rock and fluid transport properties, Gulf professional publishing.

\section{Publisher's Note}

Springer Nature remains neutral with regard to jurisdictional claims in published maps and institutional affiliations.

Submit your manuscript to a SpringerOpen ${ }^{\circ}$ journal and benefit from:

- Convenient online submission

Rigorous peer review

- Open access: articles freely available online

High visibility within the field

- Retaining the copyright to your article

Submit your next manuscript at $\boldsymbol{\wedge}$ springeropen.com 